\title{
Segmented Partisanship in a Federal System*
}

\author{
Michael A. Maggiotto, Bowling Green State University \\ Gary D. Wekkin, University of Central Arkansas
}

One intention of American federalism, according to Madison, was to provide different contexts into which politics might be organized. Segmented partisanship is a reflection of and a response to the differentiation of power, roles and opportunities that federal ism made possible. Accepting partisanship as a collection of schemata, choice among which is contextually determined, permits us to see a greater consistency among performance evaluations and electoral decisions, on the one hand, and partisanship on the other, than a single, global schema allows.

\section{Introduction}

If we imagine political cognitions as hierarchically ordered, such that a smaller number of more abstract concepts structure more numerous, concrete observations, then one would expect to place party identification fairly high up the hypothetical pyramid. One would expect this placement because one of the roles of partisanship -- a long-term, relatively stable psychological identification with a political party -- is the organization of more transient, short-term phenomena at the pyramid's base. This observation is nothing more than the vertical analogue of the funnel of causality (Campbell et al. 1960). Such a hierarchical ordering is not an uncommon rendering of political cognitions (Conover and Feldman 1981; Hurwitz and Peffley 1987; Lau 1986; Lodge and Hamill 1986; Lodge et al. 1989; Maggiotto 1991), especially if we think of political cognitions as cognitive schemata (Fiske and Taylor 1984). ${ }^{1}$

Unfortunately, by focusing attention on the vertical dimension, hierarchical depictions generally ignore horizontal relations. Pictorially and conceptually, this was the problem that underlay exclusive reliance on recursive models to explain the linkage between partisanship and electoral choice. The introduction of nonrecursive models (Franklin 1984; Franklin and Jackson 1983; Markus and Converse 1979; Page and Jones 1979) reoriented attention to the horizontal dimension, increased predictive accuracy, and enriched the theory that related cognition to behavior.

Horizontal variability plays another role in conceptualizing partisanship, one that owes its billing to our Founding Fathers' design of a federal system. We contend that federalism, manifested in different offices and expectations for the allocations of valued things, provides the contextual stimulus that helps citizens select 
among competing cognitive hierarchies to organize political reality. This paper will show that federally segmented partisanship provides a richer theoretical foundation for, and a more accurate prediction of the ability of, partisanship to organize attitudes toward electoral behavior, retrospective evaluations of governing capacity, and, to some degree, issues than undifferentiated, global notions of partisanship.

\section{Federalism and Partisanship}

The role of political parties in organizing democratic institutions and in framing electoral choice has not been seriously questioned since Schattschneider proclaimed that "... modern democracy is unthinkable save in terms of parties" (Schattschneider 1942, 1). Similarly, at the individual level, while its predictive power has fluctuated (Nie et al. 1976), the centrality of party identification (Campbell et al. 1960) to any understanding of electoral turnout, vote direction, the assessment of candidates, the impact of issues, and the role of ideology never has been seriously disputed. If anything, the most productive research has enriched our appreciation of partisanship by demonstrating its multidimensionality and linking that multidimensionality to behavioral outcomes (Alvarez 1990; Maggiotto and Piereson 1977; Valentine and Van Wingen 1980; Weisberg 1980, 1983).

The impact of federalism on the dimensionality of partisanship in the American electorate has been largely ignored, however. With some notable exceptions among party elites in the South (Hadley 1985), among certain local and state samples (Jennings and Niemi 1966; Maggiotto and Wekk in 1987, 1989, 1992; Perkins and Guynes 1976; Wekkin 1991; Wekkin et al. 1987), and in brief excursions into the national arena (Maggiotto 1985, 1986; Niemi et al. 1987), research on the American electorate has emphasized the constancy of party identification across levels of government.

We seem to have forgotten Madison's admonition in Federalist 46: "The federal and State governments are in fact but different agents and trustees of the people, constituted with different powers, and designed for different purposes" $(1938,304-305)$. Because the scope and type of authoritative allocations may vary among levels of government, each level may engender different performance expectations among the electorate. Hence, it is both logical and of ten appropriate for voter approval, contempt or indifference to be situational or discrete and not fully generalizable across all levels of government. When party programs and personalities are linked to level-based performance expections, inter-level variation in partisan affect should be an expected, not a surprising, outcome. In brief, we should anticipate that people will respond to the different "powers and ... purposes" of national and state governments with different, if related, cognitive organizations.

This is precisely what researchers studying Canadian political behavior have identified as the principles that guide the political cognitions of Canadian mass 
publics. Long before Meech Lake and even apart from separatist sentiments among Quebecois, Canadian political behavior was uninterpretable outside of a federal framework. Dual or "split-level" partisanship -- the terms used to describe federally segmented party identification -- plays a central role in modelling how Canadians react to candidates, issue agendas and the authoritative allocations of Canadian governments (Blake 1982; Clarke et al. 1979; Elkins 1988; LeDuc et al. 1984; Uslaner 1989).

Our logic suggests that the potential for segmented identification always exists in federal systems. Federalism promotes the expression of varying political cultures, encourages a diversity of different institutional arrangements, and nurtures divergent political styles of leadership and participation. Parties respond to such uniqueness by decentralization, which allows candidates and organizations to adapt themselves to the electoral incentives of each context. Such adaptive strategies, however, permit the diverse electorate a multidimensional view of parties, and each dimension may not be equally appealing. The result can be segmented partisanship.

Recognizing segmented partisanship as a reflexion of federalism does not diminish the pivotal role of party identification in understanding political cognitions and voting behavior. Quite the contrary: the segmented concept of party identification already has helped us to refine our understanding of nettlesome issues such as crossover voting (Wekkin 1991), the placement of independentleaners in the partisan identification scale (Maggiotto and Wekkin 1988), partisanbehavioral intransitivities (Niemi et al. 1987) such as those Petrocik (1974) pointed out, and also appears to hold some promise of providing insight into dealignment and that portion of realignment that may be attributable to "party-switching" (Maggiotto 1988; Wekkin et al. 1987). Segmented partisanship is proving a boon, not a bane, to theorizing and empirical explanations.

Our theory is simple and straight-forward. Party identification presents a cluster of cognitive schemata, choice among which is contextually conditioned by level of government. As Madison predicted, the electorate has different expectations for policies and candidates at different levels of government, because different conditions and responsibilities appertain within different units of government that allocate things valued by the electorate. A voter's choice of the appropriate schema to organize or merely to process information concerning a given electoral race, issue cluster or ideological position depends heavily upon both the stimuli that the race activates and how those stimuli are refracted by the individual's political context (Huckfeldt 1986). We disregard logical contextual linkages such as those among state offices, state issues and state partisanship, in favor of arbitrary national or global constructs, at considerable conceptual peril. To dismiss such linkages is to homogenize demonstrable contextual differences and exchange schematic subtlety and richness for the simplicity and safety of a single global schema. Equally perilous is the imposition of constraints upon the inter-level linkages respondents may construct. If anything, the information processing models of social cognition theory remind us to open our theorizing to 
cognitive variety. A priori cognitive structures are merely hypotheses advanced by researchers; they are not standards by which to define the health of party politics. Hence, crossover voting (Wekkin 1988, 1991), roll-off, quick-change party registration (Jewell 1983, 1987) and regionally segmented partisan realignment (Wekkin et al. 1987) are not anomalies that augur the disintegration of the parties, but phenomena that bear witness to the contextual differentiation that an increasingly more sophisticated electorate is making. Like our neighbors to the north, the more relevant the outputs of different elements in the federal structure and the more differentiated the policy agendas of those elements become, the more likely Americans are to look at parties within their different milieux.

\section{General Hypotheses}

At the most basic level, our theory suggests that the cognitive centrality of partisanship in the electoral situation, together with its co-dependency on electionspecific stimuli, will yield a strong tie between federally segmented partisanship and federally tiered elections. Thus, for example, presidential voting behavior should be better predicted by national partisanship than state or local partisanship.

Similarly, we posit an analogous relationship between partisanship and public policy preferences and between partisanship and retrospective evaluations of governing performance. Despite the propensity of political elites to obfuscate rather than to clarify their positions (Page 1978) and the best efforts of professional consultants and single-interest pressure groups to reduce public debate to narrow national themes (Godwin 1988; Hershey 1984; Sabato 1981), the issues that form the grist of campaign rhetoric and the evaluative agenda of the electorate still generally relate to the substantive purview of the offices being contested. This is equally true of elites' (i.e. candidates') efforts to associate themselves with or avoid accountability for the actions of co-partisan incumbents. There is more than surface validity to the impact of localism on "local" elections, and this can be seen in the distinctiveness of gubernatorial contests, among others (Tompkins 1988).

At bottom, we agree most emphatically with V. O. Key that the voters are not fools. Their behavior reflects sophisticated choices whose cognitive antecedents we are only beginning to probe. As our theories come to approximate more closely the realities of choice and evaluation that voters confront, the more successfully will we understand and be able to explain their electoral behavior.

\section{Data and Methods}

The data reported below come from three sources: two exit polls of Arkansas' Second Congressional District, a mixed urban/rural district that occupies the geographic center of the state and includes most of the Greater Little Rock SMSA, and a national opinion poll. In the first Arkansas poll, interviews were held with 402 systematically selected respondents in 17 randomly selected precincts on 
general election day, November 4,1986 . Five hundred seventy-six systematically selected respondents were interviewed in a second survey conducted in the same 17 precincts, plus two additional ones, on "Super Tuesday," March 8, 1988. The socio-demography of both samples is insubstantially different from that of the District as a whole. ${ }^{2}$

A national poll examining the political views of the American electorate was conducted between February 3 and March 14, 1992. Households in the contiguous 48 states were selected using well established random digit telephone number sampling techniques. Each sampling frame was divided into replicates, with each replicate comprising a microsample. Additionally, respondents were randomly selected from within households to provide representativeness. The resulting sample of 1,531 respondents provides a 95 percent confidence interval of plus or minus two percentage points for parameter estimates reported below.

Respondents in all three surveys were asked national, state, and local adaptations of the ANES party identification question to assess segmented partisanship. In 1986, Arkansas respondents were asked for whom they voted in the general election. In 1988, the Super Tuesday respondents were asked to give summative evaluations of party performance in governing the nation, the state of Arkansas, and their local community. The complete text of the questions used from the Arkansas surveys is provided in Appendix A. Respondents to the national survey were asked which party generally offered the best candidates for various offices, which party was best able to solve the most pressing problem identified by respondents at different levels of government, which party governed best at different levels, and which party's officeholders could be trusted most. The complete text of these questions is provided in Appendix A also.

\section{The Incidence of Segmented Partisanship}

Research to date has labelled between 15 and 25 percent of local, state, and national samples as dual or multiple identifiers (Jennings and Niemi 1966; Maggiotto and Wekkin 1987, 1989; Niemi et al. 1987). The variation depends on whether local, state, and national identifications are discerned, or only state and national identifications are asked: the more levels offered, the greater the number of distinctions.

For comparative purposes, in 1986 and 1988 we note that 12.3 and 18.5 percent of our Arkansas respondents, respectively, held multiple partisanships between national and state identifications. That number jumped to 31.9 percent in 1986 and 35.6 percent in 1988 with the introduction of local identification. The differences between the two years reflect, in part, the difference between off-year and presidential year elections, and the salience of national partisanship in the latter.

In our 1992 national sample, 26.1 percent of respondents held multiple partisanships among their national, state, and local identifications, a figure that closely approximates the upper limit found in previous analyses. These are the 
respondents on whom we will focus in the national analyses reported below. However, we believe that these respondents underrepresent the true number of segmented partisans. Conceptually, we cannot ignore segmented partisanship even among those who profess the same identification across levels. The reasons and referents for the common identification may differ substantially. Thus, in line with our theory, we should just as confidently point to segmentation among seemingly global identifiers, whose rationale for identification is level-based, as among those who choose different parties at different levels. After all, the programs and philosophies of state and national parties often differ, responding, as they do, to different contexts. Moreover, it has been demonstrated empirically (Maggiotto and Wekkin 1992) that national party identification does not structure state or local identification, as speculated earlier (Jennings and Niemi 1966; Hadley 1985). In future research, we will explore open-ended questions that asked respondents what was on their minds when they offered their partisanship at different levels of government. We believe that such an analysis will permit us a clearer view of the cognitive structure of partisanship at different levels of government. The current analysis, like all previous attempts which have equated multiple and segmented partisanship, is thus guilty of systematically underestimating the incidence of segmented partisanship.

\section{Electoral Behavior and Segmented Partisanship}

The major hypothesis we investigate in this section is that national partisanship guides voting behavior for national offices, state partisanship guides voting behavior for state offices, and local identification guides voting behavior for local offices. The clearest examples of each type in our data sets are executive positions: the president at the national level, the governor and attorney general at the state level, and sheriff and mayor at the local level.

Coupling theoretical and empirical results with practical limitations leads us to search for level combinations where variability in identification may be most evident in the Arkansas samples. For example, because Arkansas is a modified one-party democratic state, variability or differentiation clearly was more likely to exist when one moved from the level of the homogeneous state to that of the heterogeneous nation, with its attendant party competition. While level-segmented identifications are conceptually distinct and empirically independent, partisanship is not independent of electoral choice. Put differently, state Democrats have more opportunity to express differences they feel through the competitive party choices of candidates and platforms offered at the national level than national Democrats are afforded by the party choices available, and the issue alternatives articulated, in state elections that frequently are uncontested. Despite its propensity for ticket-splitting at the presidential level and three Republican gubernatorial victories in the last thirty years, our primary interest in the Arkansas data is in seeing how state partisans, Democrats in particular, distribute their votes when confronted with competitive party choices. Consequently, our primary 
independent variable looks at global Democrats, global Republicans, and state Democrats who migrated to the Republican column at the national level. We deliberately have excluded Independents from this analysis to concentrate our attention on the role of parties as cognitive stimuli for partisans, who may be conceptually distinct from Independents (Valentine and Van Wingen 1980). In the

Table 1. Electoral Outcomes and Segmented Partisanship in Arkansas*

\begin{tabular}{|c|c|c|c|}
\hline & $\begin{array}{c}\text { Global } \\
\text { Democrats }\end{array}$ & $\begin{array}{c}\text { State Democrats/ } \\
\text { National Republicans }\end{array}$ & $\begin{array}{c}\text { Global } \\
\text { Republicans }\end{array}$ \\
\hline \multicolumn{4}{|l|}{1988} \\
\hline \multicolumn{4}{|l|}{ Presidential Vote } \\
\hline Democrat & $91.0 \%$ & $20.5 \%$ & $6.0 \%$ \\
\hline Republican & 9.0 & 79.5 & 94.0 \\
\hline$N=$ & 223 & 44 & 133 \\
\hline \multicolumn{4}{|l|}{1986} \\
\hline \multicolumn{4}{|c|}{ Gubernatorial Vote } \\
\hline Democrat & $81.3 \%$ & $72.0 \%$ & $39.2 \%$ \\
\hline Republican & 13.5 & 12.0 & 51.9 \\
\hline$N=$ & 208 & 25 & 79 \\
\hline \multicolumn{4}{|c|}{ Attorney General Vote } \\
\hline Democrat & $93.3 \%$ & $88.0 \%$ & $57.0 \%$ \\
\hline Republican & 2.4 & 4.0 & 25.0 \\
\hline$N=$ & 208 & 25 & 79 \\
\hline
\end{tabular}

*Percentages do not sum to 100 in all cases because of votes cast for other candidates and indications of non-voting in a particular race.

Arkansas data reported below, the clearest test of the impact of segmented partisanship will be through the swings in the responses of multiple partisans to varying stimuli in the political environment. Table 1 gives us our first glimpse of this phenomenon.

There is little ambiguity in the results for executive offices. The intended vote of multiple partisans for president in 1988 follows their Republican national identification. Their votes in 1986 for governor and attorney general, however, mirror their state identifications. In each case, their vote choices are closer to, but somewhat different from, those of the respondents who are globally attached to the party preferred at that level of government by the segmented partisan.

A multivariate analysis of national opinion data from 1992 confirms the expectations from the Arkansas data set. In Table 2, variables for national, state, and local partisanship, dichotomized as Democrat versus all others, were entered in a multivariate logistic regression analysis with two dichotomous variables measuring ideology (liberal versus all others and conservative versus all others), a 16 category income variable, and a dichotomous race variable (AfricanAmerican versus all others). The dependent variables -- presidential, gubernato- 
$432 \mid$ Michael A. Maggiotto and Gary D. Wekkin

Table 2. Segmented Partisanship and Party-Office Preferences at Different Levels of Government in the U.S.

\begin{tabular}{|c|c|c|c|c|c|c|c|c|}
\hline & \multicolumn{2}{|c|}{$\begin{array}{r}\text { Presidential } \\
\text { Preference }\end{array}$} & \multicolumn{2}{|c|}{$\begin{array}{l}\text { Gubernatorial } \\
\text { Preference }\end{array}$} & \multicolumn{2}{|c|}{$\begin{array}{l}\text { Sheriff } \\
\text { Preference }\end{array}$} & \multicolumn{2}{|c|}{$\begin{array}{l}\text { Mayoral } \\
\text { Preference }\end{array}$} \\
\hline & $b^{1}$ & $\operatorname{Exp}(b)^{2}$ & $b^{1}$ & $\operatorname{Exp}(b)^{2}$ & $b^{1}$ & $\operatorname{Exp}(b)^{2}$ & $b^{1} \quad \mathrm{E}$ & $\operatorname{Exp}(b)^{2}$ \\
\hline National Partisanship & $\begin{array}{l}1.77 \\
(.30)\end{array}$ & 5.87 & $\begin{array}{l}.78^{*} \\
(.25)\end{array}$ & 2.19 & $\begin{array}{l}.43 \\
(.27)\end{array}$ & 1.53 & $\begin{array}{l}.45 \\
(.28)\end{array}$ & 1.57 \\
\hline State Partisanship & $\begin{array}{l}.50 \\
(.29)\end{array}$ & 1.65 & $\begin{array}{l}1.07 * \\
(.25)\end{array}$ & 2.92 & - & & - & \\
\hline Local Partisanship & - & & - & & $\begin{array}{l}1.68 \\
(.27)\end{array}$ & 5.39 & $\begin{array}{l}1.80^{*} \\
(.28)\end{array}$ & 6.03 \\
\hline Liberalism & $\begin{array}{l}-.51 \\
(.38)\end{array}$ & .60 & $\begin{array}{l}-.17 \\
(.30)\end{array}$ & .85 & $\begin{array}{l}.14 \\
(.34)\end{array}$ & 1.15 & $\begin{array}{l}.59 \\
(.35)\end{array}$ & 1.81 \\
\hline Conservatism & $\begin{array}{l}-.85^{*} \\
(.38)\end{array}$ & .43 & $\begin{array}{l}-.67^{*} \\
(.30)\end{array}$ & .51 & $\begin{array}{l}-.00 \\
(.35)\end{array}$ & 1.00 & $\begin{array}{l}-.05 \\
(.38)\end{array}$ & .95 \\
\hline Income & $\begin{array}{l}-.04 \\
(.04)\end{array}$ & .96 & $\begin{array}{l}-.02 \\
(.03)\end{array}$ & .98 & $\begin{array}{l}.06 \\
(.03)\end{array}$ & 1.06 & $\begin{array}{l}.03 \\
(.03)\end{array}$ & 1.03 \\
\hline Race & $\begin{array}{l}.29 \\
(.46)\end{array}$ & 1.34 & $\begin{array}{l}.64 \\
(.43)\end{array}$ & 1.90 & $\begin{array}{c}.20 \\
(.44)\end{array}$ & 1.23 & $\begin{array}{l}1.66^{*} \\
(.43)\end{array}$ & 5.27 \\
\hline Constant & $\begin{array}{r}-1.52^{*} \\
(.43)\end{array}$ & & $\begin{array}{l}-.78 \\
(.36)\end{array}$ & & $\begin{array}{r}-2.11^{*} \\
(.41)\end{array}$ & & $\begin{array}{r}-2.28^{*} \\
(.44)\end{array}$ & \\
\hline $\begin{array}{l}\text { Goodness of Fit } \\
\% \text { Correctly Predicted }\end{array}$ & 79.56 & & 69.06 & & 73.48 & & 76.52 & \\
\hline $\begin{array}{l}\text { Chi-Square } \\
\text { df } \\
\text { Significance }\end{array}$ & $\begin{array}{l}350.56 \\
355 \\
.56\end{array}$ & & $\begin{array}{l}364.01 \\
355 \\
.36\end{array}$ & & $\begin{array}{l}363.06 \\
355 \\
.37\end{array}$ & & 363.67 & \\
\hline $\mathrm{N}$ & 362 & & 362 & & 362 & & 362 & \\
\hline
\end{tabular}

*Significant at $\mathrm{p} \leq .05$

${ }^{1}$ Table entries in this column are logistic regression coefficients with associated standard errors in parentheses.

${ }^{2}$ Table entries in this column are the exponentiated logistic regression coefficients.

rial, sheriff, and mayoral party preferences -- each were dichotomized as a Democratic preference against all others. In each equation, the party judged as usually putting forth the best candidates for that office (see item-wording in Appendix A) was more closely tied to the same level of partisanship than to the alternative provided. That is, national partisanship best predicted presidential preferences, state partisanship best anticipated gubernatorial preferences, and local partisanship keyed sheriff and mayoral preferences. The presence of national partisanship as the appropriate comparison in each equation is in response to the speculation that national partisanship somehow structures attitudes and behavior at lower levels.

To evaluate the comparative strength of the partisanship effects, the nonlinear regression coefficients have been exponentiated in the companion column 
under each contested office. Since the contrast to the appropriate level coefficient is statistically significant only at the gubernatorial level, it is only here that we will assess the comparative effects of level-based partisanship on voting behavior. The calculation is straightforward and indicates that being a state-level Democrat improves the odds of voting for Democratic gubernatorial candidates by 92 percent. The corresponding increase in the odds of supporting the Democratic candidate if the respondent declares a Democratic national partisanship is only 19 percent, by contrast. ${ }^{3}$

\section{Retrospective Evaluations and Segmented Partisanship}

In 1988, Super-Tuesday voters were asked to evaluate the stewardship of the parties at the national and state levels. The results of this summative, retrospective evaluation are found in Table 3.

Table 3. Retrospective Evaluations and Segmented Partisanship in Arkansas

\begin{tabular}{lccc}
\hline & $\begin{array}{c}\text { Global } \\
\text { Democrats }\end{array}$ & $\begin{array}{c}\text { State Democrats } \\
\text { National Republicans }\end{array}$ & $\begin{array}{c}\text { Global } \\
\text { Republicans }\end{array}$ \\
\hline Governs Nation Best & & & \\
Democrats & $71.9 \%$ & $3.4 \%$ & $.7 \%$ \\
About the same & 19.8 & 18.6 & 10.8 \\
Republicans & 8.3 & 78.0 & 88.5 \\
N= & 278 & 59 & 148 \\
Governs State Best & & & \\
Democrats & $83.3 \%$ & $72.9 \%$ & $20.3 \%$ \\
About the same & 15.3 & 22.0 & 24.5 \\
Republicans & 1.4 & 5.1 & 55.2 \\
N= & 281 & 59 & 143 \\
& & & \\
\hline
\end{tabular}

Once again, the differences are vivid and in the direction predicted by our theory. Multiple partisans follow the lead of global Republicans, their national partisanship, in adjudging Republicans the better managers of national government. However, at the state level, they revert to their state partisanship and join global Democrats in applauding the efforts of Democrats in the management of affairs in Arkansas.

The respondents in our 1992 survey were asked their retrospective evaluations also. We analyzed their responses using the same multivariate logistic regression techniques as in the last section. The results again confirm the conclusion drawn from the Arkansas data. Table 4 shows that national partisanship was the best partisan predictor of who governed best at the national level, 
while state partisanship and local partisanship were tied more closely to evaluations of state and local governing performance respectively, than was national partisanship.

Table 4. Segmented Partisanship and Summative Retrospective Evaluations of Which Party Party Governs Best at Different Levels of Government in the U.S.

\begin{tabular}{|c|c|c|c|c|c|c|}
\hline & \multicolumn{2}{|c|}{$\begin{array}{c}\text { Governs Nation } \\
\text { Best }\end{array}$} & \multicolumn{2}{|c|}{$\begin{array}{c}\text { Governs State } \\
\text { Best }\end{array}$} & \multicolumn{2}{|c|}{$\begin{array}{c}\text { Govems Local Area } \\
\text { Best }\end{array}$} \\
\hline & $b^{1}$ & $\operatorname{Exp}(b)^{2}$ & $b^{1}$ & $\operatorname{Exp}(b)^{2}$ & $b^{1}$ & $\operatorname{Exp}(b)^{2}$ \\
\hline National Partisanship & $\begin{array}{l}1.70^{*} \\
(.30)\end{array}$ & 5.50 & $\begin{array}{l}.71^{*} \\
(.26)\end{array}$ & 2.03 & $\begin{array}{l}.54^{*} \\
(.27)\end{array}$ & 1.71 \\
\hline State Partisanship & $\begin{array}{l}1.00^{*} \\
(.30)\end{array}$ & 2.73 & $\begin{array}{l}1.19^{*} \\
(.25)\end{array}$ & 3.27 & & \\
\hline Local Partisanship & - & & & & $\begin{array}{l}1.44^{*} \\
(.28)\end{array}$ & 4.21 \\
\hline Liberalism & $\begin{array}{l}-.74^{*} \\
(.34)\end{array}$ & .48 & $\begin{array}{l}.12 \\
(.31)\end{array}$ & 1.13 & $\begin{array}{l}-.10 \\
(.33)\end{array}$ & .90 \\
\hline Conservatism & $\begin{array}{r}-1.60 \\
(.41)\end{array}$ & .20 & $\begin{array}{l}-.22 \\
(.33)\end{array}$ & .80 & $\begin{array}{l}-.39 \\
(.35)\end{array}$ & .68 \\
\hline Income & $\begin{array}{l}.01 \\
(.04)\end{array}$ & 1.01 & $\begin{array}{l}-0.5 \\
(.03)\end{array}$ & .95 & $\begin{array}{l}.03 \\
(.03)\end{array}$ & 1.03 \\
\hline Race & $\begin{array}{l}-.28 \\
(.49)\end{array}$ & .75 & $\begin{array}{l}-.07 \\
(.43)\end{array}$ & .93 & $\begin{array}{r}1.12^{*} \\
(.41)\end{array}$ & 3.05 \\
\hline Constant & $\begin{array}{r}-1.78^{*} \\
(.44)\end{array}$ & & $\begin{array}{l}-.96^{*} \\
(.37)\end{array}$ & & $\begin{array}{r}-1.74^{*} \\
(.40)\end{array}$ & \\
\hline \multicolumn{7}{|l|}{ Goodness of Fit } \\
\hline$\%$ Correctly Predicted & 79.56 & & 69.06 & & 72.93 & \\
\hline Chi-Square & 323.79 & & 356.55 & & 356.75 & \\
\hline$d f$ & 355 & & 355 & & 355 & \\
\hline Significance & .88 & & .47 & & .46 & \\
\hline $\mathrm{N}$ & 362 & & 362 & & 362 & \\
\hline
\end{tabular}

*Significant at $\mathrm{p} \leq .05$

'Table entries in this column are logistic regression coefficients with associated standard errors in parentheses.

${ }^{2}$ Table entries in this column are the exponentiated logistic regression coefficients.

Because each pair of level-based partisanship variables makes a statistically significant contribution to explaining retrospective evaluations at each level of government, it is important to assess the relative strength of the partisanship coefficients. To reiterate, because the logistic regression coefficients are nonlinear, a simple contrast of size is suggestive but not definitive. As in Table 2, we must evaluate the exponentiated coefficients to assess comparative impact. This evaluation reveals strong support for our hypothesis. The increase in the odds of naming the Democrats as best able to govern the nation is 450 percent if the respondent is a national Democrat, while the increase is 173 percent if the 
respondent is a state Democrat. The odds of selecting the Democrats as best able to govern the state increase by 227 percent if the respondent is a state Democrat, but increase by 103 percent if he or she espouses a national Democratic affiliation. Finally, and most strongly, identification as a local Democratic propels the odds of finding Democrats most capable of handling local problems by 321 percent, compared to an increase of 71 percent if the respondent is a national Democrat.

\section{Public Issues, Political Trust and Segmented Partisanship}

Summative ratings provide one gauge of partisanship, as Fiorina (1981) reminds us. But as the models that Fiorina predicates on Key and Downs attest, there is a contemporaneous effect: one's view of the present is colored by the summation derived from past behavior, but the present serves as a continuous reality check on such standing decisions based on the past. Thus, it is important to ask whether, in the mind of the electorate, parties are seen to possess viable, ongoing capacities to handle the changing problems that confront government. To answer that question, we included in our national survey separate items asking respondents (1) to identify the most important problems that faced government at each level, cognizant from our theory that the problems very well could be different, and (2) which political party at that level could best deal with that problem. By asking respondents to establish their own priorities, instead of offering a series of forced choice alternatives, we tried to avoid substituting policies meaningful to the analyst for those meaningful to the respondent. We are confident, then, that the policies chosen by respondents top their list of concerns and are thus the standards against which our respondents currently measure governing ability.

Table 5 presents the logistic regression analysis examining the parties' abilities to handle the most important problems identified by respondents at different levels of government. Other effects considered, partisanship at eachlevel is more closely connected to problem solving at the same level than at different levels. Put another way, national partisanship predicts ability to handle national problems, state partisanship predicts ability to handle state problems, and local partisanship predicts ability to handle local problems. We can evaluate the relative strength of level-based partisanship in the usual manner, using the exponentiated logistic regression coefficients. The odds of naming the Democrats as most capable of solving the selected national problem increased by 152 percent if the respondent professed Democratic national partisanship, compared to an increase of 99 percent with Democratic identification at the state level. The reverse is true, and more strongly, when evaluating the increase in odds of favoring Democrats as the party best able to solve the respondent-selected state problem: a 266 percent increase in the odds is produced by Democratic state identification, compared to a 94 percent increase if the respondent identifies him or herself as a national Democrat. The parallel strength estimates at the local level are equally compel ling: an increase of 380 percent in odds ratio for local Democratic affiliation, as 
against an increase of 116 percent for national Democratic affiliation. Together with the data on summative retrospective evaluations, these data provide evidence of a partisan-issue nexus that is level-based, perfectly consistent with our theory.

Table 5. Segmented Partisanship and the Parties to Handle "the Most Important Problem" at Different Levels of Government in the U.S.

\begin{tabular}{|c|c|c|c|c|c|c|}
\hline & \multicolumn{2}{|c|}{ National Problem } & \multicolumn{2}{|c|}{ State Problem } & \multicolumn{2}{|c|}{ Local Problem } \\
\hline & $b^{1}$ & $\operatorname{Exp}(b)^{2}$ & $\mathbf{b}^{1}$ & $\operatorname{Exp}(b)^{2}$ & $b^{1}$ & $\operatorname{Exp}(b)^{2}$ \\
\hline National Partisanship & $\begin{array}{c}.92^{*} \\
(.25)\end{array}$ & 2.52 & $\begin{array}{c}.66^{*} \\
(.26)\end{array}$ & 1.94 & $\begin{array}{c}.77 \\
(.30)\end{array}$ & 2.16 \\
\hline State Partisanship & $\begin{array}{l}.69^{*} \\
(.25)\end{array}$ & 1.99 & $\begin{array}{l}1.30 \\
(.26)\end{array}$ & 3.66 & - & \\
\hline Local Partisanship & - & & - & & $\begin{array}{l}1.57 * \\
(.30)\end{array}$ & 4.80 \\
\hline Liberalism & $\begin{array}{l}-.07 \\
(.30)\end{array}$ & .94 & $\begin{array}{c}.36 \\
(.32)\end{array}$ & 1.43 & $\begin{array}{l}.50 \\
(.38)\end{array}$ & 1.65 \\
\hline Conservatism & $\begin{array}{l}-.84 * \\
(.33)\end{array}$ & .43 & $\begin{array}{l}-.40 \\
(.35)\end{array}$ & .67 & $\begin{array}{l}.14 \\
(.41)\end{array}$ & 1.14 \\
\hline Income & $\begin{array}{l}-.03 \\
(.03)\end{array}$ & .97 & $\begin{array}{l}-.02 \\
(.03)\end{array}$ & .98 & $\begin{array}{l}.00 \\
(.03)\end{array}$ & 1.00 \\
\hline Race & $\begin{array}{l}.46 \\
(.42)\end{array}$ & 1.59 & $\begin{array}{l}-.47 \\
(.45)\end{array}$ & .63 & $\begin{array}{l}.70 \\
(.45)\end{array}$ & 2.02 \\
\hline Constant & $\begin{array}{l}-.82^{*} \\
(.37)\end{array}$ & & $\begin{array}{r}-1.40^{*} \\
(.39)\end{array}$ & & $\begin{array}{r}-2.52^{*} \\
(.48)\end{array}$ & \\
\hline Goodness of Fit & & & & & & \\
\hline$\%$ Correctly Predicted & 70.44 & & 71.55 & & 78.73 & \\
\hline Chi-Square & 361.38 & & 359.31 & & 359.45 & \\
\hline $\begin{array}{l}d f \\
\text { Sienificance }\end{array}$ & ${ }_{40}^{355}$ & & $3_{43}$ & & $3_{42}$ & \\
\hline $\mathrm{N}=$ & 362 & & 362 & & 362 & \\
\hline
\end{tabular}

*Significant at $\mathrm{p} \leq .05$

${ }^{1}$ Table entries in this column are logistic regression coefficients with associated standard errors in parentheses.

${ }^{2}$ Table entries in this column are the exponentiated logistic regression coefficients.

A corollary of the partisan-issue nexus is the trust that people have in political elites to act in their best interest. The position-taking, credit-claiming, and advertising activities that candidates engage in to create a reservoir of support (Mayhew 1974; Cain, Ferejohn, and Fiorina 1987) and project an effective political persona to different electoral publics (Fenno 1978) should not operate independently of partisanship. Moreover, because both problems and capabilities are level specific, level-based partisanship should be a better predictor of trust at each level of the polity than, say, national partisanship would be across all levels.

The data in Table 6 confirm our expectations. For segmented identifiers, 
Table 6. Segmented Partisanship and the Trustworthiness of Party Officeholders to Act in the People's Best Interest at Different Levels of Government in the U.S.

\begin{tabular}{|c|c|c|c|c|c|c|}
\hline & \multicolumn{2}{|c|}{$\begin{array}{c}\text { Trust National } \\
\text { Level }\end{array}$} & \multicolumn{2}{|c|}{$\begin{array}{c}\text { Trust State } \\
\text { Level }\end{array}$} & \multicolumn{2}{|c|}{$\begin{array}{l}\text { Trust Local } \\
\text { Level }\end{array}$} \\
\hline & $b^{1}$ & $\operatorname{Exp}(b)^{2}$ & $b^{1}$ & $\operatorname{Exp}(b)^{2}$ & $b^{1}$ & $\operatorname{Exp}(b)^{2}$ \\
\hline National Partisanship & $\begin{array}{l}1.49 \\
(.26)\end{array}$ & 4.45 & $\begin{array}{l}.96^{*} \\
(.26)\end{array}$ & 2.61 & $\begin{array}{c}1.03^{*} \\
(.26)\end{array}$ & 2.80 \\
\hline State Partisanship & $\begin{array}{l}.60^{*} \\
(.26)\end{array}$ & 1.82 & $\begin{array}{l}1.18^{*} \\
(.26)\end{array}$ & 3.24 & - & \\
\hline Local Partisanship & - & & - & & $\begin{array}{l}1.44^{*} \\
(.28)\end{array}$ & 4.20 \\
\hline Liberalism & $\begin{array}{l}.12 \\
(.31)\end{array}$ & 1.13 & $\begin{array}{l}-.09 \\
(.31)\end{array}$ & .91 & $\begin{array}{l}-.14 \\
(.32)\end{array}$ & .87 \\
\hline Conservatism & $\begin{array}{l}-.59 \\
(.33)\end{array}$ & .55 & $\begin{array}{l}-.25 \\
(.03)\end{array}$ & .78 & $\begin{array}{l}-.20 \\
(.03)\end{array}$ & .82 \\
\hline Income & $\begin{array}{l}-.03 \\
(.03)\end{array}$ & .97 & $\begin{array}{l}-.05 \\
(.03)\end{array}$ & .95 & $\begin{array}{l}-.00 \\
(.03)\end{array}$ & .10 \\
\hline Race & $\begin{array}{l}.14 \\
(.43)\end{array}$ & 1.15 & $\begin{array}{l}.61 \\
(.43)\end{array}$ & 1.84 & $\begin{array}{l}1.23 * \\
(.41)\end{array}$ & 3.43 \\
\hline Constant & $\begin{array}{c}-1.06 * \\
.38\end{array}$ & & $\begin{array}{l}-.92 * \\
(.37)\end{array}$ & & $\begin{array}{c}-1.53 \\
(.39)\end{array}$ & \\
\hline Goodness of Fit & 72.38 & & 70.17 & & 72.93 & \\
\hline $\begin{array}{l}\text { Chi-Square } \\
d f \\
\text { Significance }\end{array}$ & $\begin{array}{l}356.89 \\
355\end{array}$ & & $\begin{array}{l}359.93 \\
355\end{array}$ & & $\begin{array}{l}362.27 \\
355\end{array}$ & \\
\hline Significance & .46 & & .42 & & .38 & \\
\hline$N=$ & 362 & & 362 & & 362 & \\
\hline
\end{tabular}

*Significant at $\mathrm{p} \leq .05$

${ }^{1}$ Table entries in this column are logistic regression coefficents with associated standard errors in parentheses.

${ }^{2}$ Table entries in this column are the exponentiated logistic regression coefficients.

trust in party officeholders' ability to act in the people's best interest is more closely related to level-based partisanship among segmented identifiers than it is to the comparison partisanship in each equation. These trust relationships are amenable to comparative evaluation as we have done previously. The odds of trusting Democrats at the national level increase by 345 percent if the respondent is a national Democrat, but by only 82 percent if he or she is a state Democrat. Less stark, but clearly apparent, the increases in the odds of choosing the Democrats as most trustworthy at the state level rise by 224 percent if one is a state Democrat, compared to 161 percent if one identifies oneself as a national Democrat. Finally, the odds of naming local Democrats as most trustworthy increase by 320 percent if a respondent is a local Democrat, and by 180 percent if he or she is a national 
Democrat. In each case, strong support is provided our hypotheses.

\section{Conclusion}

This paper has advanced a theory of segmented partisanship rooted in American federalism. We believe that focusing attention on the tie between the constitutional structure of the American Republican and the cognitive organizations that frame mass behavioral responses opens a new and conceptually profitable discourse. That our theory parallels developments in the study of other federal systems provides scholars of American politics with an enhanced conceptual dialogue and venue for comparative analysis.

Specifically, we have shown that level-based partisanship is more closely tied than standard global measures of partisanship to level-based electoral behavior and level-based evaluations and expectations for offices. Our methods largely have permitted respondents the latitude to identify what matters to them, without the constraints imposed by forced choice alternatives. We then connected their voting behavior, their retrospective evaluations, their current issue concerns, and their assessments of trustworthiness to partisanship analytically.

Moreover, we believe that the estimates reported here understate both the incidence of segmented partisanship and the strength of its connection to attitudes and behaviors. For example, quite apart from the need to explore level-based segmentation among those treated as global partisans, under the dominant paradigm, the higher incidence of segmented partisanship (measured only as multiple identification) in a modified one-party Democratic state such as Arkansas suggests that party competition at the state level may be an important factor in understanding the distribution of segmented partisanship across the nation. Among certain states with a culture and history of one-party hegemony over one level of government, multiple identifications may be more prevalent. Thus, a blanket estimate of 26 percent multiple partisans, consistent with the upper limit of incidence in previous national studies, may blind us to significantly higher (and lower) proportions depending upon level-based phenomena. Similarly, while ideology was included in the logistic regression equations reported above and only rarely proved to be significant, only its main effect was included. Once again, level-based factors, in certain states, may dictate its incorporation as an interaction term with segmented partisanship variables, enriching both our predictive capacities and our basic understanding of the process of political evaluation by the electorate. The same can be said about race, which proved a significant predictor, especially at the local level, in several equations.

These suggestions for further research do not diminish the value of the current study. Even measured for all practical purposes as multiple partisanship, segmented partisanship does appear to structure cognitions about party-centered choices among candidates, retrospective and current evaluations of party stewardship, and trustworthiness at different levels of government. Segmented partisan- 
ship stands as a cluster of related schemata, offering a richer interpretation of the impact of partisanship on voters' information processing patterns and political evaluations.

\section{NOTES}

The authors gratefully acknowledge the support of this research by generous grants from the National Science Foundation (SES-9212646), the University Research Council of the University of Central Arkansas, and the Faculty Research Committee of Bowling Green State University. None of these agencies is responsible for the conclusions drawn or for any errors found below.

1"[A] schema is a cognitive structure that represents organized knowledge about a given concept or type of stimulus [and] ... contains both the attributes of the concept and the relationships among the attributes" (Fiske and Taylor 1984: 140).

${ }^{2}$ For example, 86 percent of the 1986 sample respondents were white, whereas census data show 83 percent of the population of the Second District (and of Arkansas) to be white; 53 percent of the respondents were males, compared to census figures of 48 percent for both the district and the state; the median years of education completed by respondents was 13.2, compared to census figures of 12.4 for the district and 12.2 for the state; the median family income of respondents was $\$ 22,030$, compared to census figures of $\$ 22,700$ for the district and $\$ 19,114$ for the state; and the median age of respondents was 39 years, compared to census figures of 29 for the district and 31 for the state. The 1988 sample was even closer to updated census data for gender and median years of education, within sampling error for median age and racial distribution, and slightly outside of sampling error for income. In short, given that the electorate itself often underrepresents the lower end of the socioeconomic scale, the non-white and the young, these samples are very representative indeed.

${ }^{3}$ The calculation is: percent increase in probability on dependent variable $=100$ $(\operatorname{Exp}(b)-1)$. See Demaris (1992).

\section{APPENDIX A Survey Questions}

\section{1986 SURVEY}

A. Segmented Partisanship Questions:

Thinking now only of national politics, do you consider yourself to be a Democrat, a Republican, an Independent, or what?

(If Democrat): As a Democrat, do you usually consider yourself to be a strong or not-so-strong Democrat?

(If Republican): As a Republican, do you usually consider yourself to be a strong or not-so-strong Republican?

(If Independent): As an independent, do you usually consider yourself to be closer to the Democrats or to the Republicans, or to neither?

This battery was repeated substituting "state politics here in Arkansas" and "local politics here in your community" for "national politics" above, to produce the state and local partisan identification measures of segmented partisanship.

B. Retrospective evaluation of parties as governors: 
1. All in all, which political party usually does the best job of governing the United States?

2. All in all, which political party usually does the best job in governing Arkansas?

C. Ideology Question:

On most political matters, do you usually consider yourself to be a liberal, a moderate, or a conservative?

D. Voting Questions

1. In the race for Governor, whom did you vote for?

2. In the race for Attorney General, whom did you vote for?

\section{1988 SURVEY}

A. The segmented partisanship questions were identical to the ones asked in 1986.

B. The ideology question was the same one as asked in 1986.

C. Election Questions:

Who do you intend to vote for in the presidential election in November?

D. Retrospective evaluation of parties as governors:

1. All in all, which political party usually does the best job of governing the United States?

2. All in all, which political party usually does the best job of governing Arkansas?

\section{1992 SURVEY}

A. The segmented partisanship questions were identical to the ones asked in 1986.

B. Other questions used were:

1. Generally speaking, regardless of the political party you prefer, you usually think of yourself as a conservative or a liberal or a moderate on most political matters?

2. The Democratic and Republican parties offer candidates for many different offices. In your opinion, which political party generally offers the best candidate for the office of:
a. President
c. Sheriff
b. Governor
d. Mayor

3. Which national political party do you think is better able to handlethisproblem: the Democrats or the Republicans?

4. Which state political party, in your opinion, is better able to handle this problem: the Democrats or the Republicans?

5. Which local political party is better able to handle this problem: the Democrats or the Republicans?

6. All in all, which party usually does the best job of governing the United States:the Democrats or the Republicans?

7. All in all, which party usually does the best job of governing your state: the Democrats or the Republicans?

8. All in all, which party usually does the best job of governing your local community: the Democrats or the Republicans?

9. Of the two major political parties, which party's officeholders do you trust most to act in the best interest of the people at the National Level?

10. Of the two major political parties, which party's officeholders do you trust most to act in the best interest of the people at the State Level? 
11. Of the two major political parties, which party's officeholders do you trust most to act in the best interest of the people at the Local Level?

12. What race do you consider yourself to be?

13. Considering all sources of income and all salaries for all members of your house-hold, what was your total family income in 1991, before deductions for taxes or anything? Was it more than or equal to $\$ 40,000$, or less than $\$ 40,000$ ?

14. Okay, within which of the following categories did the income fall? (Categories between $\$ 5,000$ and $\$ 20,000$ )

15. Okay, within which of the following categories did the income fall? (Categories between $\$ 20,000$ and $\$ 40,000$ )

16. Was it $\$ 60,000$ or more, or less than that?

17. Okay, within which of the following categories did the income fall? (Categories between $\$ 40,000$ and $\$ 60,000$ )

18. Okay, within which of the following categories did the income fall? (Categories between $\$ 60,000$ and $\$ 75,000$ or more)

\section{REFERENCES}

Alvarez, R. Michael. 1990. The Puzzle of Party Identification: Dimensionality of an Important Concept. American Politics Quarterly 18: 476-491.

Blake, Donald E. 1982. The Consistency of Inconsistency: Party Identification in Federal and Provincial Politics. Canadian Journal of Political Science, 15: 691-710.

Cain, Bruce E., John Ferejohn, and Morris Fiorina. 1987. The Personal Vote. Cambridge, MA: Harvard University Press.

Campbell, Angus, Philip E. Converse, Warren E. Miller and Donald E. Stokes. 1960. The American Voter. New York: John Wiley \& Sons.

Clarke, Harold D., Jane Jenson, Lawrence LeDuc, and John H. Pammett. 1979. Political Choice in Canada. Toronto: McGraw-Hill-Ryerson.

Conover, Pamela J. and Stanley Feldman. 1981. The Origins and Meanings of Liberal/ Conservative Self-Identifications. American Journal of Political Science 25: 617-645.

Demaris, Alfred. 1992. Logit Modeling:PracticalApplications. Newbury Park, CA:Sage Publications.

Elkins, David J. 1978. Party Identification: A Conceptual Analysis. Canadian Journal of Political Science 11: 419-435.

Fenno, Richard F. 1978. Homestyle: House Members in their Districts. Boston: Little, Brown.

Fiorina, Morris P. 1981. Retrospective Voting in American National Elections. New Haven: Yale University Press.

Fiske, Susan T. and Shelley E. Taylor. 1984. Social Cognition. New York: Random House. Franklin, Charles F. 1984. Issue Preferences, Socialization, and the Evolution of Party Identification. American Journal of Politics 28: 459-478. and John E. Jackson. 1983. The Dynamics of Party Identification. American Political Science Review 77: 957-973.

Godwin, R. Kenneth. 1988. One Billion Dollars of Influence: The Direct Marketing of Politics. Chatham, NJ: Chatham House. 
Hadley, Charles D. 1985. Dual Partisan Identification in the South. Journal of Politics 47: 254-268.

Hershey, Marjorie Randon. 1984. Running for Office: The Political Education of Campaigners. Chatham, NJ: Chatham House

Huckfeldt, Robert. 1986. Politics in Context: Assimilation and Conflict in Urban Neighborhoods. New York: Agathon.

Hurwitz, Jon and Mark Peffley. 1987. How Are Foreign Policy Attitudes Structured: A Hierarchical Model. American Political Science Review 81: 1099-1120.

Jennings, M. Kent and Richard G. Niemi. 1966. Party Identification at Multiple Levels of Government. American Journal of Sociology 72: 86-101.

Jewell, Malcolm E. 1983. Democrat or Republican? Voters' Choice of a Primary. Paper presented at the Annual Meeting of the Southern Political Science Association, Birmingham, AL.

. 1987. Dual Party Identification: Fragmentary Evidence from National and Kentucky Surveys. Paper delivered at the Annual Meeting of the Southern Political Science Association.

Lau, Richard R. 1986. Political Schemata, Candidate Evaluations, and Voting Behavior. In Richard R. Lau and David O. Sears (eds.), Political Cognition: The Nineteenth Annual Carnegie Symposium on Cognition. Hillsdale, NJ: Erlbaum.

LeDuc, Lawrence, Jane Jenson, John H. Pammett and Harold D. Clarke. 1984. Partisan Instability in Canada: Evidence from a New Panel Study. American Political Science Review 78: 470-484.

Lodge, Milton and Ruth Hamill. 1986. A Partisan Schema for Political Information Processing American Political Science Review 80 : 505-519.

Lodge, Milton, Kathleen M. McGraw and Patrick Stroh. 1989. An Impression-Driven Model of Candidate Evaluation. American Political Science Review 83: 399420.

Madison, James. 1938. No. 46: The Influence of the State and Federal Governments Compared. In Alexander Hamilton, John Jay and James Madison, The Federalist. New York: Modern Library.

Maggiotto, Michael A. 1985. The Locus of Partisanship: A Federal Analogy. Paper delivered at the Annual Meeting of the Southern Political Science Association, Nashville, TN.

1986. Party Identification in the Federal System. Paper delivered at the Annual Meeting of the American Political Science Association, Washington, DC.

. 1988. Public Opinion in South Carolina. In Charlie B. Tyer and S. Jane Massey (eds.), Government in the Palmetto State: Perspectives and Issues. Columbia: Bureau of Governmental Research and Service, University of South Carolina.

. 1991. Cognitive Structure and Attitude Contexts: Interpreting Public Opinion on Foreign and National Security Policy in the United States. In Hans Rattinger and Don Munton (eds.), Debating National Security: The Public Dimension Frankfurt am Mein: Peter Lang GMB H: 379-402.

Maggiotto, Michael A. and James E. Piereson. 1977. Partisan Identification and Electoral Choice: The Hostility Hypothesis. American Journal of Political Science 21: 745-767.

Maggiotto, Michael A. and Gary D. Wekkin. 1987. Global Concepts and Segmented Partisans: Rejoining Theory and Data. Paper delivered at the Annual Meeting of the Southwestern Political Science Association meeting, Dallas, TX. 
1988. The Proper Placement of Independent Leamers in the Party Identification Scale. Midsouth Political Science Journal 9: 1-18.

1989. Segmented Partisanship in the Electoral Context. Paper delivered at the Annual Meeting of the Midwestern Political Science Association, Chicago, IL. . 1992. Question Order and the Multidimensionality of Partisanship. Midsouth Political Science Journal 13: 498-511.

Markus, Gregory B. and Philip E. Converse. 1979. A Dynamic Simultaneous Equation Model of Electoral Choice. American Political Science Review 73: 1055-1070.

Nie, Norman H., Sidney Verba, and John R. Petrocik. 1976. The Changing American Voter. Cambridge, MA: Harvard University Press.

Niemi, Richard G., Stephen Wright, and Lynda W. Powell. 1987. Multiple Party Identifiers and the Measurement of Party Identification. Journal of Politics 49: 1093-1103.

Page, Benjamin I. 1978. Choices and Echoes in Presidential Elections: Rational Man and Electoral Democracy. Chicago: University of Chicago Press. and Calvin C. Jones. 1979. Reciprocal Effects of Policy Preferences, Party Loyalties and the Vote. American Political Science Review 73: 1071-1089.

Perkins, Jerry and Randall Guynes. 1976. Partisanship in National and State Politics. Public Opinion Quarterly 40: 376-378.

Petrocik, John R. 1974. An Analysis of Intransitivities in the Index of Party Identification. Political Methodology. 1: 31-49.

Sabato, Larry J. 1981. The Rise of Political Consultants: New Ways of Winning Elections. New York: Basic Books.

Schattschneider, E. E. 1942. Party Government. New York: Holt, Rinehart, and Winston. Tompkins, Mark E. 1988. Have Gubernatorial Elections Become More Distinctive Contests? Journal of Politics 50: 192-205.

Uslaner, Eric M. 1989. Multiple Party Identifiers in Canada: Participation and Affect. Journal of Politics 51: 993-1003.

Valentine, David C. and John R. Van Wingen. 1980. Partisanship, Independence, and Partisan Identification. American Politics Quarterly 8: 165-186.

Wekkin, Gary D. 1988. The Conceptualization and Measurement of Crossover Voting. Western Political Quarterly 41: 105-114.

. 1991. Why Crossover Voters Are Not "Mischievous Voters": The Segmented Partisanship Hypothesis. American Politics Quarterly 19: 229-247.

Michael A. Maggiotto, and Shannon G. Davis. 1987. Party Identification and Partisan Realignment in Arkansas. Comparative State Politics 8: 8-11.

Weisberg, Herbert F. 1980. A Multidimensional Conceptualization of Party Identification. Political Behavior 2: 33-60. . 1983. A New Scale of Partisanship. Political Behavior 5: 363-376. 